\title{
The new competence concept in higher education: error or enrichment?
}

\author{
Paper presented at the AERA, New York, March 25, 2008
}

\author{
Martin Mulder \\ Judith Gulikers \\ Renate Wesselink \\ Harm Biemans
}
Department of Education and Competence Studies
Wageningen University
Social Sciences Group - bode 68
PO Box 8130
NL-6700 EW Wageningen
Netherlands
Phone: + 313174841 81; Fax: + 31317484573
Mobile: + 31620677340
Email: martin.mulder@wur.nl
Internet: www.ecs.wur.nl
Internet: www.mmulder.nl




\section{Objectives and purpose}

The purpose of this study is to make an overview of the genesis of the competence movement in the US and Europe, and to evaluate the question as to whether the new concept of competence is fruitful for higher education. There has been a strong competence movement in higher education in the US in the seventies of the last centuries (Grant et al, 1979). This was followed by the application of the concept in the design of vocational-technical education. In a study of the US Department of Education (2002) competency-based initiatives were evaluated. The general feeling was that the movement was strongly related to a behaviouristic education philosophy, modularization and mastery learning. Competence was often linked with performance improvement, and many competence profiles were developed to define the essential skill needs in occupations, and to develop standards for certification and licensure purposes. The concept of competence is also used frequently in corporate education. Especially large companies employ systems of competence management and development. Employees can assess themselves using a wide variety of tools (also e-based), or they can ask for an external assessment. Next, they can make a personal development and activity plan for further competence development. All this can be embedded in results and development oriented employee management systems.

Currently, there is much attention for the concept of competence in the EU, as well as in vocational-technical as in higher education. The European Council has decided to create one education space, which holds for higher education (the so-called Bologna process), but also for the upper part of vocational-technical education (the so-called Copenhagen process). These initiatives should support the achievement of the Lisbon goals, to create a reference knowledge economy, based on the European social model and which should be sustainable. For higher education, a process of harmonization is going on, which led to the implementation of the Bachelor-Master structure in all higher education. To support this, the Twinning project has been carried out, and the Dublin descriptors were developed. The Dublin descriptors indicate the qualification which are needed at Bachelor, Master and PhD level, as well as the competence levels of these qualifications. For vocational education, the European Qualification Framework is being developed, in which knowledge, skills and competences will be defined for all sectors and levels. This is being done in close cooperation between the Directorate of Vocational Training of the European Commission, the Directors-General of vocational training of the responsible ministries of the member states, the European social partners, sector organizations, professional associations and the agencies concerned. Various EU member states have their national competence frameworks already, developed at national (like Ireland, France and the Netherlands) or state level (like the UK, Germany, Belgium), including the same kind of actors that are mentioned at EU level. Like in the US, there is also much attention for competence development for employee management in public and private organizations in the EU (Mulder \& Collins, 2006).

The objectives of the study are twofold:

1. to make an overview of the development of the competence movement in the US and Europe and; this will be done based on an earlier study for the AERA (Mulder, 2000);

2. to evaluate the question as to whether the new concept of competence is fruitful for higher education; this will be based on an in-depth case study in higher education in the Netherlands.

\section{Perspectives and theoretical framework}


In this study competence is being conceived of as:

- integrated abilities

- consisting of clusters of knowledge, skills, and attitudes

- necessarily conditional for task performance and problem solving

- and for being able to function effectively

- in a certain profession, organization, job, role and situation.

For example, the competence of adequately making a DNA-profile in crime scene investigations requires disciplinary knowledge, skills in working with artifacts, and a attitude of accuracy, coping with pressure and integrity.

The concept of competence differs from the concept of competency, in approaches like competency-based training or competency-management, that competence is a more holistic concept, whereas competency is more behaviouristic. What we mean by this will be elaborated further in the paper (Wesselink et al, 2006; Wesselink, Biemans \& Mulder, 2007).

One of the main problems with the concept of competence is, that it is vague, since there are many definitions (Biemans et al, 2004), representing different dimensions. We distinguish discriminating and non-discriminating dimensions. These are:

\section{Discriminating dimensions}

- Peripheral ability versus core competence

- Contextual dissoluteness versus situational attachment of competence

- Function versus role related competence

- Knowledge versus ability oriented competence

- Behaviour versus capability oriented competence

Indiscriminating dimensions

- Person versus system as carrier of competence

- Specificity versus generality of competence

- Learnability versus unchangeabilty of competence

- Performance orientation versus development orientation of competence

The meaning of this distinction and the various dimensions will be explained in the paper.

The concept of competence can be dated back to Persian (in the code of Hamurabbi), Greek (in Lidya of Plato) and Roman times (in general language), is used in Europe from the $16^{\text {th }}$ century and entered professional literature in law (competence of courts and witnesses), public administration (competence of institutions), organizational structure (competence of departments or functions), management (core competence, competence management), and education and training (competence-based education) from the seventies of the last century (Mulder, 2007).

This study is based on theories regarding the limits of the prognostic validity of IQ testing and traditional assessment in education, training and selection and placement of professionals (McClelland, 1973), competence for performance improvement (Gilbert, 1978), identifying top performing managers to define their competencies (Boyatzis, 1982), implementing competence-based training and development (Zemke, 1982), using competence profiles for self assessment and development (McLagan, 1983), core competence of organizations 
(Prahalad \& Hamel, 1990), and competency frameworks (Quinn et al, 1996). Furthermore, based on various theories of education and empirical research eight principles of competencebased vocational education were developed for the empowerment of local education teams to facilitate interactive processes of curriculum deliberation (Wesselink, Mulder \& Biemans, 2007).

Furthermore, the study takes full account of the many criticisms regarding the old competency-based initiatives, and the more recent competence-based developments (Biemans et al, 2004; Mulder, Weigel \& Collins, 2007; Weigel, Mulder \& Collins, 2007). In the paper the criticisms will be reviewed and commented.

\section{Methods and techniques of inquiry}

The review of the literature on competency-based and competence-oriented education and training initiatives is based on an ongoing research program on competence development, which started during the end of the nineties of the last century. During this period of literature study various techniques were used, such as literature searches in the various digital libraries and databases, the snowball method, and expert consultation within and without the field of education and educational research. This has led to a rather comprehensive overview of the field, although we do not claim completeness.

The case study conducted for this study is based in a Dutch University and Research Center, which comprises both academic and professional education programs. The distinction between the two is based on the Dutch binary system of higher education, which consists of academic and professional programs. Until recently both types of programs were offered by different systems of higher education, universities and so-called higher vocational education. During the last couple of years the higher vocational education institutes refer to themselves as professional universities.

The mode of inquiry is a qualitative case study, using various stakeholders to evaluate the appropriateness of the concept of competence-based education in higher education. Since the use of principles of competence is professional education seems to be obvious, most attention was given to academic education. Academic education in the Netherlands however also can prepare students for professions, such as the medical, judicial of construction professions. It is however rare to see the use of competence development notions in research oriented Bachelor and Master programs, such as physics, mathematics, biology of chemistry. Therefore we identified various programs in these fields (also outside the university in which we did our case study) to collect information about the integration of the notion of competence in their programs.

The stakeholders of the study are: the board of the university, the directorate of education and research, the directorate of the educational institute of the university (under which all bachelor and master programs fall), program directors, program field committees, study organizations (student associations for professional development), and other relevant student organizations. As said, various other program directors of especially science-oriented programs were contacted for information.

\section{Data sources}

The data regarding the literature review come from the international journal databases and policy reports of national and international institutes (such as USDE, Commission of the EU, 
OECD, UNESCO, CEDEFOP), conference papers and the internet. The amount of information about the topic is overwhelming, so careful attention has been paid to select the scientific and formal policy sources as well as academic research.

Various data collection techniques were used, such as over thirty in-depth structured interviews of program directors, ongoing participatory processes (of six meetings) with the administration of the university, and two interactive focus groups with student organizations.

The data sources of the case study are eight universities in the Netherlands and over twenty five full professors of these universities, from the chairman of the board of this university, the rector magnificus (dean), the director of education and research, the director of the educational institute, program directors, and fifteen representatives of student organizations. They all provided in-depth views about competence development and preparation for the labour market of students in academic education.

\section{Results and conclusions}

The results of the study are a review of the literature on competence development and views on competence development within university programs.

The literature review showed that much of the competency theory comes from the US, although there are also various authors in Europe who have contributed to the development and dissemination of this concept, such as in the UK (around the New Vocational Qualification and Accreditation of Prior Learning), France (around the 'bilan the competence') and Germany (around the notion of 'Kompetenz')

The literature also revealed a host of criticism around the concept, regarding its use in the curriculum, designing instruction, facilitating learning, and conducting assessment. The criticism can be summarized as follows. The implementation of competence-based education is too bureaucratic, it relies too much on standardization, it does not fulfill the promise of linking education and the labor market, it is too much assessment oriented, goes against the notion of liberal education, and masks the quality differences of the various colleges and universities.

\section{Results}

In this results section, attention will be paid to the place of knowledge within competencebased education. The definition of the concept, the way in which the competence development philosophy is integrated in the curriculum, the consequences for instructional strategies, and the development and pitfalls of competence assessments. From this principles can be derived which are important for further development of competence-based education. In the conclusion section these principles will be summarized.

\section{Competence and definition}

The previous sections have made clear that opinions about competence-based education are closely related to the definition that is given to it, or how it is perceived how others conceptualize and implement the competence-based development philosophy. 
There is a multitude of definitions of the concept of competence (Biemans et al, 2004) and there is much debate internationally about the conceptualization of it. In Western Europe the general definition used for instance by the European Union in the various policy documents on the European Qualification Structure and the European Credit Transfer System for Vocational Education and Training, the definition is found to be too broad, abstract and general. In the United Kingdom however, the concept is experienced as being to narrow and outcom-oriented (Weigel and Mulder, 2006; Mulder \& Weigel, 2006).

That defining the concept is a hurdle, also appears from the reactions of various academic programs:

\section{'Thinking ... (about competence-based education) is relatively broadly disseminated, although the actual implementation is not always very clear; one can spend days discussing what a competence is or not: you don't want to do that' (university professor)'.}

When competence-based education would be purely defined as the development of specific occupational skills, this would not contribute to the education of creative researchers. This is the foundation of many critiques are given about this definition.

Competence-based education instead should be aimed at the development of balanced, useful and ethical contribution of alumni towards society. Together with that, the universities and colleges should retain the cultural heritage, knowledge-for-knowledge, philosophy and reflection. Some also mention the importance of developing attitudes in education. Others however make the remark that when attitude is beginning to play a role in the definition, it possibly becomes a useless container concept.

\section{The concept of competence in academic education - old wine in new bottles?}

An often occurring prejudice about the competence development philosophy within academic education is that this is not really an innovation, but old wine in new bottles. During the seventies and eighties of last century competence-based curriculum practices existed in higher education within the US, and experiences of many undergraduate and graduate students was that it did not really add to their professional development. Competence lists were too detailed and competencies were too fragmented.

But if competence is perceived as capability, the universities and academies have since their inception contributed to the development of competence of their students, for it has always been the purpose of these institutions to educate students to be able to fulfill a role in society. During the course of the centuries university education however has become over specialized and fragmented. Specialized knowledge became most important.

New in the competence-based education approaches however is the explicit use of it and the institutionalized use of competence-instruments like core competence models, competence profiles, course-competence matrices and competence assessments. Competences now play a role in academic education in various places around the world, both in an inside-out and outside-in mode. Inside-out use of competence instruments takes place in accountability and accreditation processes. Outside-in approaches are being followed in aligning learning lines 
and trajectories of the student, regarding learning objectives, course content, educational organization and assessment of student achievement.

\section{Knowledge and competence}

Another prejudice about competence-based education is that competence could replace knowledge. Some warn for overemphasizing skills training. This concern is being expressed in the European context (Mulder en Weigel, 2006) and in vocational education (Biemans, 2004) geuit. From the reactions from the universities it appeared that respondents were divided about the question as to whether competence-based education goes at the cost of knowledge acquisition.

Some respondents believe that by implementing competence-based education the level of academic thinking will decrease. They fear a shift of attention of knowledge development and scientific creativity towards skills development. Competence development and knowledge development are thus being juxtaposed as competing educational philosophies.

'For (future) PhD students scientific knowledge is of very great importance ... for them competence-based education is not appropriate' (university professor ${ }^{1}$ ).

That this opinion is held broader in society is also apparent from the remark of an educational director:

'... I ... still have to constantly explain that employing the conceptual framework of competence domains does not imply that that we have surrendered to criteria and standards for higher vocational education'.

Furthermore it is stated that the decreasing level of disciplinary basic knowledge of students within certain fields necessitates that more attention is needed for analytical and mathematical skills than for other occupational oriented competences.

Apart from the group who state that competence-based education stands in the way of content oriented education, another group believes that competence-based education also can support content-related academic development.

'It is possible that by using the competence-based educational philosophy students acquire a better way of studying which also contributes to the purely content-related development' (university professor).

Knowledge development and competence-based education do not have to be opposing one another therefore.

'The acquisition of knowledge and insight and the application of knowledge are also important competences' (university professor).

We contend that knowledge (from possessing to evaluating it) remains important, although in the current information and knowledge society academic and professional skills also get

\footnotetext{
${ }^{1}$ When we speak of university professor in this contribution, we mean full professors.
} 
increasingly important. About the non-knowledge oriented competences is stated that they need a clear place in educational programs, but they should not get too much emphasis.

Important (academic) skills which have been mentioned are for instance seeking information, critical reading and judging information, summarizing, writing a report of article, and presenting. Others do not want the stress these skills to much, but would want to focus on competences like being able to apply systems thinking, and analyzing complex problems. A scientifically and societal open but critical attitude is perceived of as being very important.

In short, knowledge is the foundation for professional acting (and of a scientific education program) and conditional for successful performance. The knowledge economy demands of university education that is can introduce students well in a certain academic field. However, the students should also learn to apply the knowledge which is acquired. Knowledge alone is not enough.

Competence is complementary, comprehensive, and integrating, and does not exclude knowledge development. Theoretically, knowledge is part of competence as competence comprises the collection of knowledge, skills and attitudes. Without knowledge no competence.

\section{Competence and the curriculum}

To translate the competence oriented education philosophy to the curriculum, competence profiles are being composed. In this competences are being formulated which are often supplemented with mastery levels.

A way to get to a competence profile is to start with roles and to define outputs and consequently competences for those roles. An occupation for which a student is being prepared often consists of more roles (such as research, design and consultancy). These roles are described and next outputs are being formulated. These are services and products such as analytical reports, research instruments, test results, articles, presentation and instructions. Finally, on the basis of this, competences are being defined. These are capabilities role holders need to have to be able to realise the relevant outputs.

Competences can be formulated at general level, but also at very specific level. While formulating competences in university education, over-generalization and over-specialization should both be avoided.

The Dutch-Flemish Accreditation organization (NVAO) requires that the objectives of an educational program should be described in terms of end qualifications. These end qualifications should be related to internationally used descriptions of Bachelor and Master programs in the given domain of study. For accreditations purposes competences can be used to operationalize the end qualifications. In academic education the so-called Dublin descriptors can be used (NVAO, 2003).

At the EU level, the Dublin-descriptors together form a systematic whole of competences which are important for Bachelor and Master programs:

1. Knowledge and insight.

2. Application of knowledge and insight. 
3. Development of judgment.

4. Communication.

5. Learning skills.

These rather clearly specify what a graduate should be able to do, differentiating between the Bachelor, Master and $\mathrm{PhD}$ phase, with competence which are increasingly complex.

The technical universities of Delft, Eindhoven and Twente distinguished seven competence domains which characterise a graduate from academic education (with each 6 to 8 competences):

1. Capable in one or more scientific disciplines.

2. Capable in research.

3. Capable in design.

4. A scientific approach.

5. Intellectual basic skills.

6. Capable in cooperation and communication.

7. Taking account of temporal and societal context.

Based on this methodology, within the Free University of Amsterdam meetings were held with faculty about the competences in their study components. However, the experience was that there is much overlap between the different categories and that faculty had difficulties in understanding the meaning of the competences. After that, they moved towards the description of the Dublin descriptors which went better in their perception.

Wageningen University, being a technologically oriented, but also very international university, has used the model of the three technical universities, stressing the importance of being able to think and work in a multidisciplinary way, and to take the international context into account.

Educational programs have developed matrices of competences and courses based on this competence model. The next step was to try to redesign the program for competence development of students and to link this with the examination of students. That appeared to be not easy. Then use and development of competence areas is still in full development in this university.

Another approach of developing competence profiles can be found in the Dutch Biology programs. In this competencies are being divided into knowledge competences (5), skill competences (8) and attitude competences (3-4). And within the educational institute of Chemistry at the University of Utrecht, faculty in the context of competence-based education speak about academic skills, which are allocated in three learning lines in the Bachelor program:

1. Communication (writing/presenting).

2. Doing research.

3. Context (philosophy of science and ethics).

The Open University uses an approach which is aimed at study tasks. For this, several models are developed in which competence assessment in included. 
'The starting point is that good education rests upon an explicit educational design in which the consequences for the educational exploitation (financing) is also considered' (university professor).

A reaction from someone who has been busy with the development of competence profiles is that it was an eye-opener, because before faculty used to define knowledge items as educational objectives. However, a critical remark here is that the expectations as to the elaboration and measurability of competences may appear to be too high:

'It is still about objectives which take shape and change while working' (university professor).

The reactions of the universities in this study showed that faculty are still searching for the way in which competences should be integrated in the curricula of the programs.

Some have the experience that they unconsciously go to far in the development process:

'You want to achieve [...] a bit too many things [...] which in fact not all students need to master, but with which they should be acquainted' (university professor)

'... then you get a whole paper circus, of which many feel that this is not feasible and thus adds little to directing the programs in the right way' (university professor).

This is a big difference created between the paper competences and the real competences which are being developed during the program. This goes along with warnings against the bureaucreatic use of competence instruments in academic education. In similar vain a professor of one of the universities stated that he thinks it is useful to define the competences within the educational programs at general level, but that it in practices has grown to the extent that it isa cult with all kind of forms that need to be completed in a very detailed way.

'Of course, diverse academic skills and competences are addressed in various courses, in a natural way. Use that and do not add skills in an artificial way to courses. That does not work, and furthermore it goes at the cost of the content-related part of the course' (university professor).

About a competence-based curriculum in a university context it is also stated that the individual aspect of an educational program towards becoming an academic.

'(...) that requires broadly and not too tightly formulated competences' (university professor).

\section{Competence and instruction}

Competence-based education often goes together with the implementation of principles of activating student learning. According to those principles students are expected to collect information by themselves and to solve problems in groups. This changes the role of the teacher and that of the student. The experience is that teachers give less and less information 
and instruction to students. Many fear that the level of mastery of basic skills is decreasing by that (Weigel en Mulder, 2006).

Biemans et al (2004) describe the experiences in vocational education and show that the changing role of teachers and students can easily be overlooked. It is therefore seen as important that structural attention is being paid to the competence development of teachers and education managers.

Learning in practice is formulated as condition for competence-based education, but in reality it appears to be problematic to combine learning with practice. A method in higher education which is being employed for this purpose is problem-based education (PBE).

A remark frequently made about PBE as educational method is that the group work which is involved is not always appreciated. Students currently also want to perform and excel individually, and they do not always divide the work in a fair way. Many times there are students who try to take a free ride with the consequence that that the total quality of the group work decreases.

A countervailing remark of one of the respondents in the study was:

'Academic learning in the exact sciences is often perceived as an individual activity, whereas the work of a researcher in a research group is often characterized as teamwork. That also has to be learned during the study' (university professor).

PBE could therefore be used to develop teamwork competence. In other research was found that PBE positively influence other competences such as being able to work interdisciplinary, being able to apply field specific knowledge and methods, being able to plan, coordinate and organize, the problem solving capacity, and reflective skills (Vaatstra en de Vries, 2007).

Good instruction during the implementation of this educational method remains necessary to really reach the positive effects and to prevent gaps in the knowledge base of students. In many cases educational designers and teachers expect too much of students regarding knowledge construction by themselves via internet and the literature.

'A general complaint of students in the beginning of the program is that they find PVE too vague and that they cannot judge by themselves what is good and wrong (and also get too little feedback of the teachers about that), so that they are not fully sure about their views and ideas and what they should or should not know' (university professor)

PBE is being mentioned often within the context of the competence-based development philosophy to indicate that it is not useful to exclusively design and implement competencebased education. Some institutions have gone to far in that respect during the last decade.

'Innovations in education are necessary, but they should be introduced carefully'(university professor).

\section{Competence and assessment}

Competences are being described in a profile, included in courses via innovative educational methods and subsequently students need to be assessed to determine whether they sufficiently 
achieved the required competences. There are various testing or assessment methods for self assessment, assessment by independent assessors or 360-degrees feedback. Designing a personal development plan (PDP) can be used to give students information about the mastery of the competences in the curriculum. In the PDP agreements can be registered about the priorities of the competences to develop, and the strategies to realize that, such as training, workplace learning, coaching, and intervision.

Many institutions currently are in the phase of development assessment standards and procedures. Some have gone through a pilot stage, others still have to think about the way in which they will make the competences they defined testable.

Within the Technical University of Eindhoven staff and students use the University Paper (UP), which comprises an assessment that can display the level to which students of a program as a group meet the criteria of bachelor and master courses. A pilot is carried out with students of three study programs. The method appeared to be useful. The conclusion was that the University Paper should be made ready for:

- 'assessing the academic profile and level of a student population of a programs (such as at the beginning of the program, at the end of the program, during the application for a Master program, and periodical assessment) in the framework of the internal quality policy;

- comparing programs in terms of the academic profile in the context of accreditation/visitation;

- $\quad$ assessing individual students'. (http://w3.tm.tue.nl/; 2006-12-18).

At the Free University of Amsterdam the respondent stated that many competence do get attention, but that they are hardly or not being tested. They do work on defining levels of mastery and on making competences assessable now. Also, for competence domains within bachelor programs continuous learning lines are being developed and aligned to the implementation of a (digital) portfolio.

About keeping a portfolio another respondent stated that this can be a way to have students develop skills without giving much explicit attention in the regular educational program. In this way students should also develop the capacity to manage and monitor these things by themselves.

In the literature and by the respondents various critical remarks are being made while using competence assessments. Biemans et al (2004) and Mulder, Weigel \& Collins (2006) identified the following challenges in this respect:

- competence-assessment costs much time;

- competence-assessment goes with high costs;

- the development of competences takes long, because of which it is difficult to test them during the educational program;

- competences are being formulated in general terms, so that they do not have any discriminating power in assessments;

- the assessment of performance of persons frequently takes place in simulated professional contexts, by which there is no guarantee that the same person will also act competently in a real professional context;

- analysts of profiles of competences do not always have the availability of sufficient capability and trustworthiness to judge whether certain persons are competent or not. 
The reactions of the Dutch universities confirm that time and costs of assessments are an obstacle for implementation. The Theology program of the Free University went a step back after a pilot project with portfolios because of the time that was needed to invest in it. Others limit extensively documented feedback, '(...) to not increase the administrative burden of faculty too much'.

\section{Conclusions and recommendations}

The empirical part of the study showed that:

- professional higher education is competence-oriented by its very nature.

- academic higher education can make effective use of the concept of competence, knowledge is the largest part of the professional competence of an academic, and therefore knowledge remains the largest part of the curriculum; course-competence matrices can help to identify the competence-oriented learning trajectories;

- representatives of student organizations value the notion of competence development and preparation for the labor market;

- various student organizations are very active in the field of competence development; several are using competence profiles of committee or board members, and use 360-degree feedback mechanisms for informing candidates about their competence levels;

- student organizations would like to see relationships between what they do and what the academic programs do in terms of competence development (such as to develop a personal portfolio - digital or not - and personal development plans);

- the perceptions and preferences of full professors regarding the use of competence development in academic education varies from critical ('it is more bureaucracy and does not lead to better academic education') to supportive ('It is essential for academic programs to pay attention to competence development, also when the program prepares for research; researchers are also working in teams and need to share and communicate); others point to the mere fact that the programs must comply with the needs of society (which should be made transparent in accreditation processes);

- representatives of educational administration have a general feeling that the educational programs need to cover the most important competencies, and that this can be supported by competence assessment in the Bachelor programs by assessing the academic skills, and in the Master programs by assessing the occupational preferences of the students, both to help them choose and develop better;

- competence should be integrated in the academic programs, but for various skills, special time should be reserved for specific teaching and learning of these skills, such as communication, critical reflection, information literacy, teamwork, project management skills.

Finally, we have learned that when the concept of competence is being used in discussions about educational innovations, it should be made clear that the present use of the concept is different from the way the concept was used in the seventies and eighties of the last century. 
The principles behind the current innovation should be made clear, otherwise the participants in the discussion immediately switch off, and start showing symptoms of regression ('You know, I participated in a competence-based education program, and it was $\mathrm{f}$... bad'), whereas there are many reactions of teachers and participants in competence-based education who appreciate the principles behind it, and who are positive about the outcomes ('Students are more independent, show more self-efficacy and initiative, and have stronger problem solving skills').

Most universities are active with the introduction and implementation of a competenceoriented educational philosophy. Most reactions about the usefulness of competence development within academic education are positive. Gathering content-oriented knowledge however remains of importance, but in the modern information and knowledge society academic skills are getting increasingly important. Apart from that, competence-based education is effectively aligned with the goal that the graduate is functioning well in the rapidly developing global society.

There still is some concern about what exactly is meant by competence, whether this comprises practical skills which are being taught in technical-vocational education and training, or that they also embrace academic skills. As a consequence of this there are differences of opinion about the question as to whether competence-based education will negatively influence the disciplinary knowledge of the students.

Practically speaking, the implementation of the competence-oriented development philosophy goes with various challenges, such as time investment, costs and the changing organization or education. During the design of the competence profiles developers can loose their clear sight on practice. A consequence can be that the competence profiles do not serve as a practical tool for development, but a paper exercise.

Competence-based education is frequently flown in from different direction, not taking into consideration the coherence between educational objectives, the content of the program, the organization of the study, and the assessment of educational achievement. If educational developers work on one of these pillars this has consequences for the others. During the introduction of competence-based education this coherence should be taken into account in a careful way.

Combining all reactions from the various universities in this study, the following recommendations can be formulated:

- Aim the competence-based education at a balanced, useful and ethical contribution of the program and its graduates to society. Preserve the idea that science is a cultural good, knowledge for the sake of knowledge can be worthwhile in the long run, and philosophy and reflection play an important part in academic education.

- Good academic education is resting on an explicit educational design in which the consequences for educational exploitation (financing) is considered. Improvements and innovations in education are necessary but should be introduced with care. Be cautious with exaggerating the introduction of a new educational concept by over-specification of competences. Also in this educational concept, provide sufficient diversity in educational methods.

- Keep an eye on the individual aspect of an academic educational program. Each individual needs unique competences. Because of that it is important to allow broad margins and to not to specify the competences to tightly. 
- Maintaining a portfolio can be used as an instrument to support competence development, without giving the concept explicit attention in the communication with students.

- Pay sufficient attention to the changing role of the teacher and student during the introduction of competence-based academic education.

Further research should be started to show differential relationships between the level of integration of the competence concept in higher education and the societal effects of the respective programs.

\section{References}

Biemans, H., L. Nieuwenhuis, R. Poell, M. Mulder \& R. Wesselink (2004). Competencebased VET in The Netherlands: backgrounds and pitfalls. Journal of Vocational Education and Training, 56, 4, 523-538.

Grant, G., P. Elbow, T. Ewens, Z. Gamson, W. Kohli, W. Neumann, V. Olesen \& D. Riesman (1979). On Competence. A Critical Analysis of Competence-Based Reforms in Higher Education. San Fransisco: Jossey-Bass.

Mulder, M. (2000). Creating Competence: Perspectives and Practices in Organizations. Paper presented at AERA, New Orleans. Enschede: University of Twente. Faculty of Eductional Science and Technology.

Mulder, M. (2002). Competentieontwikkeling in organisaties. Perspectieven en praktijk. 'sGravenhage: Elsevier Bedrijfs Informatie.

Mulder, M. (2007). Competence - the essence and use of the concept in ICVT. European Journal of Vocational Training, 40, 5-22.

Mulder, M. \& Bruin-Mosch, C. (2005). Competence development in organizations in EU member states. ECS Bulletin, 3, 1, 6-10.

Mulder, M. \& K. Collins (2007). Competence development in selected EU member states. Paper presented at the Annual Meeting of the AERA in Chicago.

Mulder, M., Wesselink, R. \& Bruijstens, H. Chr.J. (2005). Job profile research for the purchasing profession. International Journal of Training and Development. 9, 3, 185-204.

Mulder, M., J.M. van Loon \& R.A.J.M. Broekman (2004). Lessen uit Onderwijsinnovatie binnen Omgevingswetenschappen - LOO. Wageningen: Wageningen Universiteit en Researchcentrum, Environmental Sciences Group/Educatie and Competentie Studies.

Mulder, M., T. Weigel \& K. Collins (2006). The concept of competence concept in the development of vocational education and training in selected EU member states. A critical analysis. Journal of Vocational Education and Training, 59, 1, 65-85.

Mulder, M., R. Wesselink, H. Biemans, L. Nieuwenhuis \& R. Poell (Red.) (2003). Competentiegericht beroepsonderwijs. Gediplomeerd, maar ook bekwaam? Houten: Wolters-Noordhoff.

Trowler, P. (2004), Policy and Change: Academic development units and the Bologna

Declaration, International Journal for Academic Development, Vol. 9, No. 2: 195-200.

Vaatstra, R., R. de Vries (2007). The effect of the learning environment on copetences and training for the workplace according to graduates. Higher Education 53: 335357. 
U.S. Department of Education, National Center for Education Statistics (2002). Defining and Assessing Learning: Exploring Competency-Based Initiatives. NCES 2002-159, prepared by E.A. Jones \& R.A. Voorhees, with Karen Paulson, for the Council of the National Postsecondary Education Cooperative Working Group on CompetencyBased Initiatives. Washington, D.C.: U.S. Department of Education.

Weigel, T., M. Mulder \& K. Collins (2007). The concept of competence in the development of vocational education and training in selected EU member states. Journal of Vocational Education and Training, 59, 1, 51-64.

Wesselink, R., H.J.A. Biemans \& M. Mulder (2007). Competence-based VET as seen by Dutch researchers. European Journal of Vocational Training. 40, 38-51.

Wesselink, R., M. Mulder, E. R. van den Elsen \& H.J.A. Biemans (2006). Developing competence-based VET in the Netherlands. Paper presented at the Annual Meeting of the AERA, 2006, San Francisco, USA.

Wesselink, R., M. Mulder, H. Biemans (2007). Evaluation of the Utility of a Model for Competence-Based VET. Paper presented at the Annual Meeting of the AERA, Chicago, April 9-13. Wageningen: Wageningen University, ECS.

http://w3.tm.tue.nl/nl/capaciteitsgroepen/av/platform_academische_vorming/projecten/onder zoek_competenties_studenten/ (2006-12-18).

$\mathrm{http}: / /$ nvao.net/content.php? $\mathrm{a}=\mathrm{s} \& \mathrm{id}=85$ Accreditatiekader bestaande opleidingen hoger onderwijs (2003) (20-12-2006). 